\title{
Fritt sykehusvalg for alle?
}

\author{
Høyt utdannede bruker fritt sykehusvalg oftere enn folk med lav utdanning.
}

\section{«Flere menn enn kvinner benytter seg av fritt sykehusvalg»}

Fritt sykehusvalg innebærer at en pasient kan velge å bli behandlet på et annet sykehus enn lokalsykehuset. Ordningen ble innført i Norge i 2001. Siden den gang har ventetidene gått ned over hele landet. Forskning viser imidlertid at det er stor forskjell på hvem som benytter seg av tilbudet.

Studien, som benyttet pasientadministrative data fra 1999-2005 koblet med data fra Statistisk sentralbyrå, omfattet om lag 500000 pasienter som var behandlet innenfor diagnosegrupper som tilbys over hele landet. Resultatene viste at pasientmobiliteten økte da fritt sykehusvalg ble innført, særlig innenfor de enkelte helseregionene. Jo lengre ventetid, desto mer benyttet pasientene seg av muligheten til å bytte sykehus.

- Høyt utdannede brukte muligheten oftere enn de med lavere utdanning. Dette skyldes muligens at ressurssterke pasienter er bedre informert om hvilke rettigheter de har, sier Afsane Bjorvatn, som er førsteforfatter av studien og forsker ved Samfunnsog næringslivsforskning i Bergen (SFN).

Hun tror også at denne gruppen er mer helsebevisst enn de med lavere utdanning.

Studien viste at menn er mer villige til å reise bort for å få behandling enn kvinner. - Dette kan skyldes at kvinner opplever det vanskeligere å reise fra små barn, sier Bjorvatn. At de med alvorlige diagnoser reiste lenger enn de som var friskere, overrasker heller ikke forskeren.

- Det er et problem at ordningen i størst grad har kommet ressurssterke grupper til gode. Myndighetene må sørge for at alle pasienter kjenner til retten til fritt sykehusvalg, slik at flest mulig kan benytte seg av den, sier Bjorvatn.

Kari Tveito

Tidsskrifte

\section{Hederspris til Morten Rostrup}

\author{
Morten Rostrup (f. 1958) har mottatt Arne Næss' \\ hederspris for sin innsats for de aller svakeste \\ i verden.
}

Rostrup startet Leger Uten Grenser i Norge i 1996, og han ble senere president for Médecins Sans Frontières (MSF) International. Han var også med på å motta Nobels fredspris på vegne av Médecins Sans Frontières.

Som feltarbeider i Leger Uten Grenser har Morten Rostrup vært i mange krigssoner. Siden 1996 har han vært i Rwanda, Kongo, Tanzania, Angola, Sudan, Kosovo, Liberia, Afghanistan, Irak, Indonesia, Tsjad, Darfur, Kenya, Haiti, Libya, Syria, Egypt og nå sist i Ukraina.

Hedersprisen skal hedre medmenneskelighet og uegennyttig innsats gjennom lang tid for å motivere og inspirere andre.

- Morten Rostrup er en meget spesiell person. Han har i mange, mange år viet livet sitt til å hjelpe de aller svakeste i verdens farligste områder, sier Leif Landsverk som er juryleder for prisen.

Den erfarne feltlegen bor på Grønland i Oslo, og når han er hjemme, sykler han til og fra jobben ved Intensivavdelingen, Oslo universitetssykehus, Ullevål, der han jobber i halv stilling. I et liv som leves i verdens konfliktområder er det viktig å ha en trygg base.

- Du vet at du har et sted å vende tilbake til, som er trygt og godt, og da er det mye lettere å kunne jobbe andre steder, også i konfliktområder, sier Rostrup.

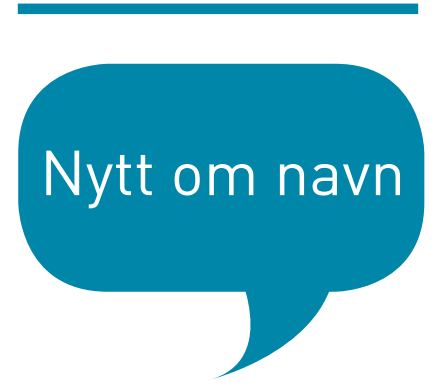

Bjørn Skogen er overlege ved Universitetssykehuset Nord-Norge og professor ved Institutt for medisinsk biologi ved Universitetet i Troms $\varnothing$. Han har fått Innovasjonsprisen til Universitetet i Troms $\varnothing$ for utviklingen av en vaksine mot den potensielt dødelige tilstanden neonatal alloimmun trombocytopeni (NAIT) hos nyfødte.

(uit.no)

Marit Hermansen er kommunelege og leder i Norsk forening for allmennmedisin. Hun advarer mot helseapper og er skeptisk til mobildiagnostisering. - Diagnostisering er det leger som skal stå for, det er ikke så lurt å stå for den selv, sier hun. (nrk.no)

Alexander Börve er lege og gründer av en mobilapp som skal gi svar på om man er smittet av en kjønnssykdom. Börve avviser Datatilsynets advarsel og forsikrer at det er helt trygt å sende bilder av kjønnsorganer gjennom STD Triage-appen. (ba.no) 